\title{
Influence of interpersonal communication of Chairman and Employees on employee performance Inna Parapat Hotel and resort
}

\author{
Syafrisya Fazhari ${ }^{\text {a,1,* }}$, Rudianto ${ }^{\text {b,2 }}$ \\ ${ }^{a}$ University og Muhammadiyah Sumatera Utara, Jl. Kapten Muchtar Basri No.3, Glugur Darat II, Kec. Medan Tim., Kota Medan, Sumatera Utara 20238 \\ ${ }^{1}$ fazharisyafrisya@gmail.com*; ${ }^{2}$ rudianto@umsu.ac.id \\ * corresponding author
}

Article history

Received 09-11-2021

Revised 10-11-2021

Accepted 11-11-2021

Keywords

Influence

Interpersonal Communicarion

Employee Performance

Inna Parapat hotels and resorts

\begin{abstract}
This research is motivated by the rapid growth of technology and the increasingly dynamic patterns of human communication both as personal and interpersonal. This study aims to determine the influence of interpersonal communication between leaders and employees on employee performance at Inna Parapat Hotel and Resort. The theory used in this research is De Vito's theory which emphasizes interpersonal communication patterns while the employee performance approach uses the Robbins theory. The research method used is quantitative. This type of research uses associative research or research to determine the relationship between two variables. The study population was 93 people and 48 people were sampled using simple random sampling as the sampling technique. The data obtained is the result of a questionnaire whose answers are accumulated and described in narrative form. The conclusion from the research conducted is the influence of interpersonal communication on employee performance at the Inna Parapat Hotel and Resort.
\end{abstract}

This is an open access article under the CC-BY-SA license.

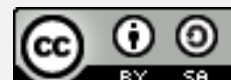

\section{Introduction}

A company has communication that is so complex, that is, the process of delivering messages that are not limited and refers to systematic, persuasive messages, and forms a communication pattern where the messages have been arranged by company leaders or this can be said to be interpersonal communication. A leader in interpersonal communication can create forms and patterns of communication for the company (Brenner \& Igamberdiev, 2021).

The authority possessed by the leadership can make this happen. A leader usually when conducting interpersonal communication has taken experiences from other places or places before he has led and integrated his personality so that these things can determine how interpersonal communication with employees.

Communication that should be implemented by a leader is by conducting open communication both about work and the company so that nothing is hidden or hidden. This is useful for the progress and interests of a company. However, open communication does not guarantee the best for the company. Besides, a leader can see, understand, and follow up on employees in various conditions. That way, leaders must be able to create harmonious communication and can improve employee performance (ALkharashi, 2019). 
Open communication that occurs with employees will get complete information. Then open communication also makes an impact on the implementation of work to motivate employees and improve performance harmonization within the company.

Companies that have an increase or decrease in work productivity can be caused by the effectiveness of the company's communications. Effective communication can achieve the goals of a company by requiring good cooperation between leaders and employees. Therefore, it is necessary to know how big the real influence of the leadership is on the employee performance of the Inna Parapat Hotel and Resort. The purpose of this study was to determine the effect of interpersonal communication between leaders and employees on employee performance at Inna Parapat Hotel and Resort (O’Neill \& Mattila, 2010).

\section{Theorotocal Framework}

Interpersonal communication is communication that takes place directly or faces to face between one or two people that is personal or special. Someone or individuals who carry out communication are basically due to survival and to maintain their needs that individuals can adapt to their environment.

There are four aspects to interpersonal communication, namely: (a) Performed by two or more people when communicating, (b) Face to face or face to face, and use certain media such as telephones and cell phones, (c) Use informal or non-standard language, such as using regional languages, or a combination of several languages, and so on, (d) When communication occurs in society, the goals to be achieved are personal/personal, if communication takes place within the scope of the organization, the goal is to carry out a task or job.

Active interpersonal communication also has a role in developing and changing employees. The changes that occur with the communication and interaction process are expected to have an impact on increasing enthusiasm, adding inspiration, as well as motivation and feelings. The discussion discussed in interpersonal communication is so diverse and very complex, depending on the goals of the individuals in communicating (Putra \& Smolek, 2020).

Effective interpersonal relationships must be carried out with interpersonal communication so that all individuals involved in interpersonal communication can be open to each other, trust each other, support, and develop attitudes to understand and develop each other's qualities.

Based on the form, the interpersonal communication process can occur verbally or non-verbally. Meanwhile, based on its nature, interpersonal communication can be formal or informal. Interpersonal communication patterns that occur in an organization are more informal. So that the language used to convey messages in interpersonal communication within the organization is also not formal because this communication emphasizes the delivery of messages. The main thing in interpersonal communication is to make the recipient of the message able to understand the message conveyed properly (Paramitha, 2020).

De Vito in (Berger \& Roloff, 2019) says that interpersonal communication (interpersonal communication) is a message sent by someone to another with a direct message effect. Furthermore, Liliweri also quoted Barnlund's opinion which said that interpersonal communication is communication that is always connected with a meeting between two, three, or four people that occurs spontaneously and without structure.

Interpersonal communication is communication carried out face-to-face by two people which allows each person to receive direct verbal or nonverbal responses or reactions. This communication has a special form, that is, children who only involve two people, such as husband and wife, two friends, and so on (Solomon \& Theiss, 2020).

According to Berger \& Roloff (2019) states that interpersonal communication or dyadic communication is a form of communication between two people that occurs in the form of conversation or direct contact. the contact that takes place can be made face to face (face to face) using the media, such as by telephone, and has reciprocal or two-way communication. 
According to Konijn, Utz, Tanis, \& Barnes (2008), interpersonal communication has several components, namely:

\section{Sender-Receiver}

The individual in interpersonal communication involves at least two people. Communication that occurs in interpersonal communication designs and sends messages as well as receives and interprets messages. Interpersonal communication must be related to humans, not machines, pictures, or animals, or other objects. Interpersonal communication occurs in two people or small groups (Lihui, Xianjun, \& Whinston, 2005).

\section{Encoding-decoding}

The action that produces a piece of information or message is called encoding, where the messages are arranged in advance using words, symbols, and so on. Meanwhile, decoding is the act of understanding and interpreting the messages received. The context of interpersonal communication has both sending messages as well as receiving messages, thus it can be said that the encoding function in interpersonal communication is carried out by everyone involved in the communication (Miller, 2014).

\section{Message}

The messages that exist in interpersonal communication can be in the form of words (verbal) or symbols, symbols, (non-verbal), or a combination of verbal and non-verbal forms.

\section{Media / Channels}

This channel serves as a bridge that connects the sender and receiver of information. In interpersonal communication, it is common for the perpetrators to meet face-to-face. Media / Channel has a function to connect between communicators and communicants. In general, communicators and communicants communicate directly or face to face (face to face).

\section{Distraction}

Often the messages sent are different from the messages received. This is due to interference during communication. In interpersonal communication, this disorder includes three things.

The messages that have been conveyed are often different from the messages received by the recipient. This happens because when communicating directly experience communication problems. Disturbances in interpersonal communication include 3 things, namely: (1) Interference that comes from outside (physical) that interferes with the process of transmitting messages, such as distance, seizure, noise, and so on, (2) The distraction that exists due to different interpretations and subjective judgments with the recipient of the message. Differences in attitudes, status, values, and even emotions can hinder communication. This disorder is known as a psychological disorder, (3) Disturbances that occur due to symbols or words used in communication, otherwise known as semantic disturbances. Semantic disturbances have more than one meaning/meaning so that communicators often fail to understand the message conveyed (McRae et al., 2010).

\section{Feedback}

An equally important role in the interpersonal communication process is feedback. Feedback can be positive or negative. Positive feedback will generate profits and negative feedback will result in losses. However, feedback can be neutral if the responses are mediocre. Besides, we don't only get feedback from other people, but we can get feedback from our messages by hearing our voices and correcting them if there are errors (Moir, 2020).

Success in communicating will be determined by the skills of the leader and employees so that they can achieve business goals. If a company has bad communication it will damage the company's relationship with various internal and external parties. A damaged or bad relationship with various parties will make the company lose money, as employees will often make mistakes.

One of the triggers to emerge and improve employee performance between superiors and subordinates is having a good working relationship. Besides, communication and work relations between employees and superiors, among employees must also be good. The company as a whole 
can improve coordination between employees or divisions, increase cohesiveness, productivity by conducting horizontal communication.

In other words, it can be said that communication has a role in a company. This communication process is a tool by the company which is expected to enable employees or employees to have a good plan and performance. Therefore, communication has a relationship with employee performance. Based on this description, it can be concluded that the role of communication is to achieve a growing and improving employee or employee performance on an ongoing basis (Moir, 2020).

According to Nurlaila (2013) performance or commonly known as performance is the result or output of a process. Meanwhile, according to Luthans (2005) someone who does work and produces something or service in quantity or quality with a behavioral approach in management.

Performance is the level of success or results of a person in carrying out a task within a certain period which has various possibilities such as targets or targets, predetermined and mutually agreed with criteria as well as work standards.

\section{Method}

The method used in this research is the quantitative method. A quantitative approach can be interpreted as a research method based on the philosophy of positivism, used to research on certain populations or samples, data collection using research instruments, quantitative/statistical data analysis, to test predetermined hypotheses. The population in this study were all employees of Inna Parapat Hotel and Resort totaling 93 people. The sample used in this study using the Slovin formula is the sample in this study amounted to 48 (Wahidmurni, 2017).

\section{Results and Discussion}

After the text edit has been completed, the paper is ready for the template. Duplicate the template file by using the Save As command, and use the naming convention prescribed by your conference for the name of your paper. In this newly created file, highlight all of the contents and import your prepared text file. You are now ready to style your paper; use the scroll down window on the left of the MS Word Formatting toolbar.

Table 1. Respondents' Answers Frequency Distribution Value on the Effect of Interpersonal Communication or Independent Varials (X).

\begin{tabular}{clll}
\hline o. & Category Interval & Frequency & Percentage (\%) \\
\hline 1 & Very good $\geq 72$ & 30 & $62.5 \%$ \\
2 & Good 66-71 & 11 & $22.9 \%$ \\
3 & Enough 60-65 & 5 & $10.4 \%$ \\
4 & Bad 54-59 & 1 & $2.08 \%$ \\
5 & Very bad 48-53 & 1 & $2.08 \%$ \\
\hline Total & & $\mathbf{4 8}$ & $\mathbf{1 0 0 \%}$ \\
\hline
\end{tabular}

From the table above it can be concluded that from the statement of all respondents said that interpersonal communication has a very good category with a percentage of $62.5 \%$ or as many as 30 people, either category with a percentage of $22.9 \%$ or as many as 11 people, enough category with a percentage of $10.4 \%$ or as many as 5 people, the bad category was $2.08 \%$ or 1 person, and the very bad category was $2.08 \%$ or as many as 1 people. Therefore, it can be said that the influence of interpersonal communication is in the very good category. 
Table 2. Value Distribution of Respondents' Answers Frequency of Employee Performance or Bound Variables (Y)

\begin{tabular}{clll}
\hline $\begin{array}{c}\text { N } \\
\text { o. }\end{array}$ & Category Interval & Frequency & Percentage (\%) \\
\hline 1 & Very good $\geq 72$ & 16 & $33.3 \%$ \\
2 & Good 66-71 & 9 & $18.6 \%$ \\
3 & Enough 60-65 & 17 & $35.4 \%$ \\
4 & Bad 54-59 & 5 & $10.4 \%$ \\
5 & Very bad 48-53 & 1 & $2.08 \%$ \\
\hline Total & & $\mathbf{4 8}$ & $\mathbf{1 0 0 \%}$ \\
\hline
\end{tabular}

The table above can be concluded from the statements of all respondents regarding the employee's performance in the very good category with a percentage of 33.3\% or as many as 16 people, in the good category with a percentage of $35.4 \%$ or as many as 17 people, in the bad category with a percentage of $10.4 \%$ or as many as 5 people, and the very bad category with a percentage of $2.08 \%$ or as much as 1 person. Therefore, it can be said that employee performance is in a sufficient category.

By using the determination test to find out how much the percentage of influence of variable $\mathrm{X}$ (influence of interpersonal communication) on variable $\mathrm{Y}$ (employee performance), the results obtained from the previous calculation $\mathrm{rxy}=0.803$, therefore, the next calculation is as follows:

$$
\begin{aligned}
\mathrm{D} & =(\mathrm{rxy}) 2 \times 100 \% \\
& =(0.803) 2 \times 100 \% \\
& =0.64 \times 100 \% \\
& =64 \%
\end{aligned}
$$

Based on the results of the above calculations, the determination test value is $64 \%$ so that the effect of interpersonal communication on employee performance is $64 \%$, while $36 \%$ is due to other factors.

The results obtained from the $\mathrm{r}$ value can be seen directly by using the correlation table to see whether the value of $r$ obtained is meaningful or not. Significant $r$ limits are listed in the correlation table and show a significant value of 5\%. Because $r$ gets a significant result, this indicates that the value of $r$ influences interpersonal communication (variable $\mathrm{X}$ ) on employee performance (variable $\mathrm{Y})$. Therefore, it can be said that the correlation of the effect of interpersonal communication (variable X) on employee performance (variable Y) has an interpretation level between $0.80-1,000$, or in other words, it can be said to be very strong. It means that the influence of interpersonal communication on employee performance is true.

Hypothesis testing that has been obtained shows the results that the hypothesis is accepted as true, this is because after doing the calculation shows the value of $r x y=0.803>$ then with the $r$-value table which is as many as 48 people with a significant level of percentage of $5 \%$, the $\mathrm{r}$ table value is 0.284. Thus, the hypothesis is accepted because there is an influence on interpersonal communication (variable $\mathrm{X}$ ) on employee performance (variable $\mathrm{Y}$ ) at Inna Parapat Hotel and Resort.

So, the results of the above analysis show that the effect of interpersonal communication is very good so that it can be maintained again. For the adequate category, employee performance needs to be maintained and coaching and strive even better to achieve the desired vision, mission, and goals efficiently and effectively. 


\section{Conclusion}

Based on the results of the research, the level of influence of interpersonal communication between leaders and employees on the performance of employees of Inna Parapat hotels and resorts is in the very good category, which is $62.5 \%$. Then the level of employee performance at Inna Parapat hotels and resorts is in the moderate category, which is $35.4 \%$. and the results of the hypothesis test obtained show that the proposed hypothesis is accepted as true, this is because after doing the calculation shows the value of $\mathrm{rxy}=0.803>$ by looking at the table $\mathrm{r}$ benchmark, namely a sample of 48 people with a significant level of $5 \%$, the $r$-table value is 0.284 . Therefore the alternative hypothesis is accepted. There is the influence of variable $\mathrm{X}$ (influence of interpersonal communication) on variable Y (employee performance) at Inna Parapat Hotel and Resort.

\section{Acknowledgment}

We would like to thank all those who have helped in completing the research. I also thank the Communication Science Study Program at the Muhammadiyah University of North Sumatra, which is a place to gain knowledge that is always superior, intelligent, and reliable.

\section{References}

ALkharashi, N. A. (2019). Brief communication. Saudi Medical Journal. https://doi.org/10.15537/smj.2019.12.24643

Berger, C. R., \& Roloff, M. E. (2019). Interpersonal communication. In An Integrated Approach to Communication Theory and Research, Third Edition. https://doi.org/10.4324/9780203710753-24

Brenner, J. E., \& Igamberdiev, A. U. (2021). Communication. In Studies in Applied Philosophy, Epistemology and Rational Ethics. https://doi.org/10.1007/978-3-030-62757-7_12

Konijn, E. A., Utz, S., Tanis, M., \& Barnes, S. B. (2008). Mediated interpersonal communication. In Mediated Interpersonal Communication. https://doi.org/10.4324/9780203926864

Lihui, L., Xianjun, G., \& Whinston, A. B. (2005). A sender-receiver framework for knowledge transfer. MIS Quarterly: Management Information Systems. https://doi.org/10.2307/25148677

McRae, K., Hughes, B., Chopra, S., Gabrieli, J. D. E., Gross, J. J., \& Ochsner, K. N. (2010). The neural bases of distraction and reappraisal. Journal of Cognitive Neuroscience. https://doi.org/10.1162/jocn.2009.21243

Miller, T. (2014). Encoding-Decoding. In The International Encyclopedia of Communication. https://doi.org/10.1002/9781405186407.wbiece067.pub2

Moir, T. (2020). Feedback. In Feedback. https://doi.org/10.1007/978-3-030-34839-7

Nurlaila, P. A. (2013). The use of mind mapping technique in writing descriptive text. Journal of English and Education.

O'Neill, J. W., \& Mattila, A. S. (2010). Hotel brand strategy. Cornell Hospitality Quarterly. https://doi.org/10.1177/1938965509352286

Paramitha, A. (2020). Komunikasi efektif komunitas rumah baca dalam meningkatkan minat baca pada anakanak di dusun Kanoman. COMMICAST, 1(1), 1. https://doi.org/10.12928/commicast.v1i1.2408

Putra, F. D., \& Smolek, S. (2020). Peace language and conflict resolution in harmony communication. International Journal of Communication and Society, 2(2), 86-93. https://doi.org/10.31763/ijcs.v2i2.134

Solomon, D., \& Theiss, J. (2020). Culture and Interpersonal Communication. In Interpersonal Communication. https://doi.org/10.4324/9780203147832-10

Wahidmurni. (2017). PEMAPARAN METODE PENELITIAN KUALITATIF. Educational Psychology Journal. 